This site uses cookies. More info $\boldsymbol{\otimes}$ Close By continuing to browse the site you are agreeing to our use of cookies. Find out more here Close

the omi

Research Methods \& Reporting

\title{
Use of serial qualitative interviews to understand patients' evolving experiences and needs
}

BMJ 2009; 339 doi: https://doi.org/10.1136/bmj.b3702 (Published 28 September 2009) Cite this as: BMJ 2009;339:b3702

Scott A Murray, St Columba's hospice professor of primary palliative care, Marilyn Kendall, research fellow, Emma Carduff, research fellow, Allison Worth, research fellow, Fiona M Harris, research fellow, Anna Lloyd, research fellow, Debbie Cavers, research fellow, Liz Grant, senior lecturer, Aziz Sheikh, professor of primary care research and development

${ }^{1}$ Primary Palliative Care Research Group, Centre for Population Health Sciences: General Practice Section, University of Edinburgh, Edinburgh EH8 9DX

Correspondence to: S A Murray scott.murray@ed.ac.uk

- Accepted 26 March 2009

Interviewing patients over the course of their illness can give a much better picture of their experience than single interviews, but the approach is rarely used. Scott Murray and colleagues explain how to get the most from it

Longitudinal qualitative research offers considerable advantages over the more typical single "snapshot" techniques in understanding patients' changing experience of illness. Serial qualitative interviews are a convenient and efficient approach to developing an ongoing relationship between the participant and researcher, thereby facilitating discussion of sensitive and personal issues while also allowing exploration of changing needs and experiences.

Serial interview studies are widely used by social science researchers in anthropology, criminology, education, psychology, and social policy.123456 However, they remain underused in medicine.7 Using our experience with the technique, we suggest when researchers might wish to use serial interviews and discuss the methods, the data generated, and how to avoid potential pitfalls.

\section{When to use serial interviews}

Serial interviews are suitable for research that aims to explore evolving and complex processes or when time is needed to develop a relationship between researcher and participants. We have used the approach to study the changing experiences and needs of people with lung and brain cancers, heart failure, severe chronic obstructive pulmonary disease, and spiritual distress, and access to care for south Asian patients at end of life (table $\underline{\Downarrow}$ ).8 91011 Others have shown the value of this approach in, for example, understanding childhood asthma, exploring stigma related to HIV infection, reconstruction of self identity after diagnosis of chronic fatigue syndrome, complex clinician- 
patient interactions around requests for physician assisted suicide, and the symptom course in childhood cancer.12

13141516

\begin{tabular}{|c|c|c|c|c|c|}
\hline Aim of study & Participants & Recruited by & $\begin{array}{c}\text { Timing of } \\
\text { initial } \\
\text { interview }\end{array}$ & $\begin{array}{l}\text { Approximate } \\
\text { interval of } \\
\text { interviews } \\
\text { (months) }\end{array}$ & $\begin{array}{l}\text { Length } \\
\text { of study } \\
\text { (months) }\end{array}$ \\
\hline $\begin{array}{l}\text { To compare the } \\
\text { illness } \\
\text { trajectories, } \\
\text { needs, and } \\
\text { service use of } \\
\text { patients with } \\
\text { cancer and } \\
\text { those with } \\
\text { advanced non- } \\
\text { malignant } \\
\text { disease }\end{array}$ & $\begin{array}{l}20 \text { patients } \\
\text { with } \\
\text { inoperable } \\
\text { lung cancer } \\
\text { and } 20 \text { with } \\
\text { advanced } \\
\text { heart failure, } \\
\text { plus their } \\
\text { family and } \\
\text { professional } \\
\text { carers }\end{array}$ & $\begin{array}{l}\text { Respiratory } \\
\text { physicians } \\
\text { and } \\
\text { cardiologists }\end{array}$ & $\begin{array}{l}\text { Lung } \\
\text { cancer: at } \\
\text { diagnosis } \\
\text { Heart } \\
\text { failure: at } \\
\text { hospital } \\
\text { discharge }\end{array}$ & 3 & 12 \\
\hline $\begin{array}{l}\text { To inform future } \\
\text { service } \\
\text { developments } \\
\text { for people with } \\
\text { advançed heart } \\
\text { failure }\end{array}$ & $\begin{array}{l}30 \text { patients } \\
\text { with } \\
\text { advanced } \\
\text { heart failure, } \\
\text { their family, } \\
\text { and } \\
\text { professional } \\
\text { carers }\end{array}$ & $\begin{array}{l}\text { Cardiologists } \\
\text { and } \\
\text { geriatricians }\end{array}$ & $\begin{array}{l}\text { Hospital } \\
\text { admission } \\
\text { or } \\
\text { outpatient } \\
\text { attendance }\end{array}$ & 6 & $12-18$ \\
\hline $\begin{array}{l}\text { To understand } \\
\text { the experience } \\
\text { of being } \\
\text { diagnosed and } \\
\text { living with a } \\
\text { brain tumour }\end{array}$ & $\begin{array}{l}26 \text { patients } \\
\text { with } \\
\text { suspected } \\
\text { malignant } \\
\text { glioma and } \\
\text { their family } \\
\text { carers }\end{array}$ & $\begin{array}{l}\text { Neurosurgical } \\
\text { team }\end{array}$ & $\begin{array}{l}\text { During } \\
\text { process of } \\
\text { diagnosis }\end{array}$ & $\begin{array}{l}\text { Prediagnosis, } \\
\text { pretreatment, } \\
\text { post- } \\
\text { treatment, } 6 \\
\text { month follow- } \\
\text { up, } \\
\text { bereavement }\end{array}$ & $\begin{array}{l}12 \text { or till } \\
\text { death }\end{array}$ \\
\hline $\begin{array}{l}\text { To identify the } \\
\text { needs and } \\
\text { service use of } \\
\text { patients with } \\
\text { chronic } \\
\text { obstructive } \\
\text { pulmonary } \\
\text { disease and to } \\
\text { map a } \\
\text { framework for } \\
\text { an intervention } \\
\text { study }\end{array}$ & $\begin{array}{l}20 \text { patients } \\
\text { with severe } \\
\text { disease, their } \\
\text { family, and } \\
\text { professional } \\
\text { cares }\end{array}$ & $\begin{array}{l}\text { Respiratory } \\
\text { physicians } \\
\text { and general } \\
\text { practitioners }\end{array}$ & $\begin{array}{l}\text { Severe } \\
\text { disease, } \\
\text { criteria } \\
\text { from range } \\
\text { of tests }\end{array}$ & 6 & 18 \\
\hline
\end{tabular}




\begin{tabular}{|c|c|c|c|c|c|}
\hline Aim of study & Participants & Recruited by & $\begin{array}{c}\text { Timing of } \\
\text { initial } \\
\text { interview }\end{array}$ & $\begin{array}{c}\text { Approximate } \\
\text { interval of } \\
\text { interviews } \\
\text { (months) }\end{array}$ & $\begin{array}{l}\text { Length } \\
\text { of study } \\
\text { (months) }\end{array}$ \\
\hline $\begin{array}{l}\text { To understand } \\
\text { end of life care } \\
\text { needs of South } \\
\text { Asian patients } \\
\text { in Scotland and } \\
\text { to understand } \\
\text { barriers and } \\
\text { facilitators to } \\
\text { accessing } \\
\text { services }\end{array}$ & $\begin{array}{l}25 \text { patients, } \\
\text { their family, } \\
\text { and } \\
\text { professional } \\
\text { carers }\end{array}$ & $\begin{array}{l}\text { General } \\
\text { practitioners, } \\
\text { community } \\
\text { organisations }\end{array}$ & $\begin{array}{l}\text { Thought } \\
\text { by general } \\
\text { practitioner } \\
\text { to be in } \\
\text { last year of } \\
\text { life }\end{array}$ & 6 & 18 \\
\hline $\begin{array}{l}\text { To describe the } \\
\text { spiritual needs } \\
\text { of patients } \\
\text { approaching } \\
\text { death and to } \\
\text { explain how } \\
\text { and by whom } \\
\text { such needs } \\
\text { could best be } \\
\text { met } 11\end{array}$ & $\begin{array}{l}20 \text { patients } \\
\text { and their } \\
\text { general } \\
\text { practitioners }\end{array}$ & $\begin{array}{l}\text { General } \\
\text { practitioners }\end{array}$ & $\begin{array}{l}\text { Thought } \\
\text { by general } \\
\text { practitioner } \\
\text { to be in } \\
\text { last year of } \\
\text { life }\end{array}$ & 3 & 6 \\
\hline
\end{tabular}

Details of six serial in-depth interview studies

Serial interviews can also be used to identify changes in what patients want, the most acceptable way to carry out interventions, and which outcomes are most important to patients at what times. Allowing the participant-researcher relationship to develop over time enables the generation of more private accounts and descriptions of sensitive topics that are less accessible in initial interviews. Serial interview studies can also be embedded within complex intervention studies in order to try to elucidate causal pathways. For example, we are including serial interviews in our trial of using lay outreach workers for smoking cessation in order to understand why they are (or are not) effective.

\section{How do you conduct serial interview studies?}

\section{Recruitment}

The timing of initial recruitment is important and is best driven by a sound understanding of the likely trajectory of the illness and the main issues to be explored.17 For example, we recruited patients with lung cancer at the point of diagnosis; those with heart failure at the time of their admission to hospital-when supportive and palliative care needs become particularly relevant; and patients with glioma before formal diagnosis in order to capture their experiences from this distressing time onwards. However, when prognostic uncertainty is great, the timing of recruitment for initial and subsequent interviews can be difficult to determine.

Location of recruitment also needs consideration. Identification in hospital can be successful for patients with rare conditions, who can then be followed up in the community. However, different situations may require recruitment in other healthcare settings or even outside health care. Irrespective of where participants are recruited from, working closely with all professionals involved is crucial to ensure appropriate and ongoing access to participants. In order to 
make the best use of resources inclusion and exclusion criteria must be well defined, including the stage of the illness.

\section{Data generation}

Variable attrition rates and illness progression will affect the timing of second and subsequent interviews. For example, we used three month intervals in people with recently diagnosed lung cancer but six monthly interviews in people with chronic obstructive pulmonary disease, which progresses less rapidly. Researchers should identify expected transitions or key points in the course of an illness and return to speak with participants at those stages. We have also found it useful to use telephone contact to assess if an interview should be brought forward to capture a changing event. The time needed for repeat interviews must be factored into the research design timetable.

Data generation must continue long enough to describe and understand the trajectory being studied. In patients with lung cancer, for example, data collection for 12 months from diagnosis will capture most deaths, but longer will be needed in a study of frail elderly patients.

\section{Analysis}

Initial analysis of transcripts of individual interviews and field notes should take place immediately, alongside continuing data generation. This allows emerging themes and concepts to be further tested and developed in subsequent interviews. Analysis may also be done across all first, second, and subsequent interviews or data synthesised from interviews at specific key points, such as immediately preceding death.

Adequate time and resources need to be allocated to allow the various longitudinal analytical opportunities to be fully exploited. Analysing all transcripts for each person as a longitudinal single unit will provide a sense of individual experience, whereas broad thematic approaches build cross-cutting themes, but at the expense of individual contexts. The longitudinal datasets generated, being typically rich in narratives, allow innovative approaches to both transcribing and analysis. For instance, as the required coding in qualitative analysis can result in fragmentation and de-contextualisation, we have transcribed some parts of the interviews of heart failure and lung cancer patients in stanza forms, as epic poetry. These can provide an accessible insight into the patient's experience.

\section{What type of findings might you expect?}

\section{Issues that change over time}

Serial interviews can elicit changing needs or opinions-for example, in our lung cancer study some participants went from initial enthusiasm about having chemotherapy to regret, and others from refusal to deep appreciation of hospice care in later interviews. We were also able to capture the fluctuating existential anguish of increasing physical and cognitive debility in serial interviews with glioma patients and their carers. Similarly, Baker and colleagues interviewed bone marrow transplant recipients and noted changing physical problems and anxiety levels as the treatment progressed, with a feeling of impending doom emerging in later interviews.18 The serial interviews provided a rich insight into the multifaceted roles of patients within their families and communities and the way in which these served to preserve patients' identity over time.

Serial interviews can also show how patients' experiences can be affected by external factors such as the influence of health services on their conceptualisation of illness over time.19 20 Furthermore, serial interviews allow fluctuating and often asynchronous patterns of physical, social, psychological, and spiritual distress to be discerned. The approach allowed us to map typical trajectories of physical decline in people with cancer and organ failure.21 We were also able to identify typical but asynchronous trajectories of psychological, social, and spiritual distress as disease progressed in patients with advanced lung cancer.21 22 We were able to describe archetypal typologies of 
decline by following individual cases over time. This gave a much clearer picture than would have been possible by simply comparing snapshot data at different stages in the disease.

\section{Rich and contextualised accounts}

Repeating interviews allows narratives to unfold, revealing the complexity of individual situations, and helps participants and researchers to highlight deficiencies of care and make suggestions to improve services.

Experiences since the last interview can be shared, with the earlier findings being developed and reflected on in the context of an evolving, participant-researcher relationship. The resulting continuous and changing account would be difficult, if not impossible, to construct from a series of snapshot interviews. Additionally, the trust fostered by repeated contact enables participants to voice sensitive or embarrassing issues and allows more private (as opposed to public) accounts to emerge.23 We have found that repeated interviews give participants implicit permission to broach what was previously unspeakable, facilitating frank and honest discussions that might otherwise not have occurred. Detailed and contextualised accounts of sensitive illness experiences can therefore emerge.

\section{Pitfalls and how to avoid them}

\section{Ethical issues}

Ethical problems are potentially heightened in longitudinal research, including concerns around serial consent, especially if the patient is deteriorating or vulnerable.19 24 Intrusion, dependency, and distortion of life experience must also be avoided.25 But we have found that patients can, and indeed want to, talk about personal and sensitive issues such as death, dying, and bereavement. Patients have said that it is sometimes easier for them to talk to a researcher rather than a clinician about these issues, and that by voicing their internal fears they have been more able afterwards to speak to their family members and friends. Serial interviews also give participants the opportunity to voice their concerns and distress and make a societal contribution through research in response to the care they have received.26 27

Serial interview research can place considerable demands on researchers because it is inherently an emotionally charged process. Researchers' responsibility does not end with a final interview, and it is important to protect the wellbeing of researchers as well as participants. Accordingly, we recommend counselling and debriefing sessions for both researchers and transcribers, who should ideally have adequate maturity, experience, and access to personal or emotional support.24 Our experiences confirm that these concerns about wellbeing can be adequately addressed and that interviewing very ill patients need not be exceptionally stressful.28

\section{Attrition}

As with any longitudinal research, attrition can be problematic. For example, in one study of people with glioma, none of the planned second interviews were possible because of participants' cognitive decline and lack of energy after radiotherapy.29 Steinhauser and colleagues emphasise the importance of establishing participant-interviewer rapport from the first point of contact to try maximise retention.30 If a firm relationship is built up between researcher and participant, few participants will be lost, except through debility or death. None theless, attrition should be factored into the design of the study. We found that by recruiting and interviewing patients and their relatives early in their illness we were able to establish relationships that facilitated interviews with relatives after patients' deaths. Grieving relatives often felt more able to take part in a bereavement interview with someone they knew and trusted, and who knew and understood their journey.

\section{Data overload}

The serial interview approach inevitably generates a large volume of interviews. The data can become difficult to manage, particularly when second and subsequent interviews have started. Effective planning is therefore essential 
from the outset. Furthermore, the time consuming nature of the analysis creates the danger that the process is becoming unmanageable—something that has been described as an analytical albatross.31

\section{Conclusions}

An understanding of the dynamic effects of disease on people's everyday lives is a prerequisite to delivering more accessible and acceptable care. People centred longitudinal research methods can make a major contribution in our understanding.32 Serial in-depth interviews are a powerful method that resonates with the clinical aim to provide continuity of contact with patients and their families. The method is also possibly the most affordable in-depth data generation technique, and our experiences suggest that it is also likely to prove acceptable to clinicians.

Lack of awareness and concerns about some theoretical, methodological, and planning considerations currently limit use of this study design. Many of these barriers can be overcome with appropriate planning and groundwork, and although the approach is research intensive, we believe the benefits are well worth achieving. Participants consistently report serial interviews as helpful rather than harmful; researchers also find that such interviewing can be rewarding. 24

\section{Summary points}

Serial interviewing studies can give important insights into patients' changing experiences of illness

The increased contact with participants allows a deeper relationship to develop, facilitating discussion of sensitive issues

Theoretical and methodological concerns can be overcome with careful planning

Although the method is time consuming, the benefits are well worth achieving

\section{Notes}

Cite this as: BMJ 2009;339:b3702

\section{Footnotes}

- We thank the Chief Scientist's Office of the Scottish Government, the Department of Health, London, Macmillan Cancer Support, the Economic and Social Research Council, and E Wiseman for funding the studies.

- Contributors: SAM, MK, and AS conceived the paper, and all the authors wrote it and have approved the final draft. SAM is the guarantor.

- Competing interests: None declared.

- Provenance and peer review: Not commissioned; externally peer reviewed.

\section{References}

1. Kemper R, Royce A. Chronicling cultures: Long term field research in anthropology. Walnut Creek, CA: AltaMira, 2002.

2. Smith D, McVie S. Theory and method in the Edinburgh Study of Youth Transitions and Crime. $\mathrm{Br} J$

Criminology2003;43:169-95. 
3. White RT, Arzi HJ. Longitudinal studies: designs, validity, practicality, and value. Res Sci Educ2005;35:137-49.

4. Gilligan C. In a different voice: psychological theory and women's development. London: Harvard University Press, 1993.

5. Corden A, Millar J. Time and change: a review of qualitative longitudinal research literature for social policy. Soc Pol Society 2007;6:583-92.

6. Smith N, Lister R, Middleton S. Longitudinal qualitative research. In: Becker S, Bryman A, eds. Understanding research for social policy and practice: themes, methods and approaches. Bristol: Policy Press, 2004.

7. Lewington S, Whitlock G, Clarke R, Sherliker P, Emberson J, Halsey J, et al. Blood cholesterol and vascular mortality by age, sex, and blood pressure: a meta-analysis of individual data from 61 prospective studies with 55,000 vascular deaths. Lancet2007;370:1829-39.

8. Murray SA, Boyd K, Kendall M, Worth A, Benton TF, Clausen H. Dying of lung cancer or cardiac failure: prospective qualitative interview study of patients and their carers in the community. BMJ2002;327:929.

9. Murray SA, Worth A, Boyd K, Kendall M, Hockley J, Pratt R, et al. Patients', carers' and professionals' experiences of diagnosis, treatment and end-of-life care in heart failure: a prospective, qualitative interview study. London: Department of Health, British Heart Foundation, 2007.

10. Worth A, Irshad T, Bhopal R, Brown D, Lawton J, Grant E, et al. Vulnerability and access to care for South Asian Sikh and Muslim patients with life limiting illness in Scotland: prospective longitudinal qualitative study. BMJ2009;338:b183.

11. Grant E, Murray SA, Kendall M, Boyd K, Tilley S, Ryan D. Spiritual issues and needs: perspectives from patients with advanced cancer and non-malignant disease. A qualitative study. Palliat Support Care2004;2:371-8.

12. Peterson JW, Sterling YM. Children's perceptions of asthma: African American children use metaphors to make sense of asthma. J Pediatr Health Care2009;23:93-100.

13. Buseh AG, Stevens PE. Constrained but not determined by stigma: resistance by African American women living with HIV. Women Health 2006;44:1-18.

14. Whitehead L. Toward a trajectory of identity reconstruction in chronic fatigue syndrome/myalgic encephalomyelitis: a longitudinal qualitative study. Int J Nurs Stud2006;43:1023-31.

15. Back AL, Starks H, Hsu C, Gordon JR, Bharucha A, Pearlman RA. Clinician-patient interactions about requests for physician-assisted suicide: a patient and family view. Arch Intern Med2002;162:1257-65.

16. Woodgate RL, Degner LF. Cancer symptom transition periods of children and families. J Adv Nurs 2004;46:358-68.

17. Lawton J, Peel E, Parry O, Douglas M. Shifting accountability: a longitudinal qualitative study of diabetes causation accounts. Soc Sci Med2008;67:47-56.

18. Baker F, Zabora J, Polland A, Wingard J. Reintegration after bone marrow transplantation. Cancer Practice 1999;7:190-7.

19. Lawton J. Gaining and maintaining consent: ethical concerns raised in a study of dying patients. Qual Health Res2001;11:693-705.

20. Lawton J, Peel E, Parry O, Araoz G, Douglas M. Lay perceptions of type 2 diabetes in Scotland: bringing health services back in. Soc Sci Med2005;60:1423-35.

21. Murray SA, Kendall M, Boyd K, Sheikh A. Illness trajectories and palliative care. BMJ2005;330:1007-11.

22. Murray SA, Kendall M, Grant E, Boyd K, Barclay S, Sheikh A. Patterns of social, psychological, and spiritual decline toward the end of life in lung cancer and heart failure. J Pain Symptom Manage2007;34:393-402.

23. Cornwell J. Hard-earned lives: accounts of health and illness from east London. London: Tavistock, 1984.

24. Kendall M, Harris F, Boyd K, Sheikh A, Murray SA, Brown D, et al. Key challenges and ways forward in researching the "good death": qualitative in-depth interview and focus group study. BMJ2007;334:521-4.

25. Yates P, Stetz KM. Families' awareness of and response to dying. Oncol Nurs Forum 1999;26:113-20.

26. Lowes L, Paul G. Participants' experiences of being interviewed about an emotive topic. J Adv Nurs2006;55:587-95.

27. Harris FM, Kendall M, Bentley A, Maguire R, Worth A, Murray S, et al. Researching experiences of terminal cancer: a systematic review of methodological issues and approaches. Eur J Cancer Care2008;17:377-86. 
28. Murray SA, Sheikh A. Serial interviews for patients with progressive diseases. Lancet2006;368:901-2.

29. Wideheim AK, Edvardsson T, Pahlson A, Ahlstrom G. A family's perspective on living with a highly malignant brain tumor. Cancer Nurs 2002;25:236-44.

30. Steinhauser KE, Clipp EC, Hays JC, Olsen M, Arnold R, Christakis NA, et al. Identifying, recruiting, and retaining seriouslyill patients and their caregivers in longitudinal research. Palliat Med2006;20:745-54.

31. Holland J, Thomson R, Henderson S. Qualitative longitudinal research: a discussion paper. Economic and Social Research Council, 2006. www.Isbu.ac.uk/families/workingpapers/familieswp21.pdf.

32. Riley J, Ross JR. Research into care at the end of life. Lancet2005;365:735-7. 